\title{
Viduriniosios kartos (gimusiųjų 1970-1984 m.) apsirūpinimo būstu galimybès Lietuvoje
}

\author{
Rasa Indriliūnaitè \\ Vytauto Didžiojo universitetas \\ Jonavos g. 66, LT-44191 Kaunas
}

cross $^{r e f}$ http://dx.doi.org/10.5755/j01.ppaa.19.3.27444

\begin{abstract}
Anotacija. Straipsnyje analizuojamos individualaus apsirūpinimo būstu galimybès Lietuvoje, apibrëžtos po nepriklausomybès atkūrimo šalyje susiformavusiu dualistinès būsto politikos modeliu, pasižyminčiu ribota valstybès atsakomybe už gyventoju būsto poreikius ir rinkos veikëju kontroliuojamu privačiu būsto fondu. Daugeliui moderniu büsto politikos sistemu pastaraisiais dešimtmečiais išgyvenant intensyvius kaitos procesus dèl finansiniu kriziu padariniu ir besitraukiančios gerovès valstybès keliamu iššūkiu, tiek dualistinèse, tiek unitarinèse būsto sistemose stebimas augantis privataus būsto sektorius bei mažejanti valstybès parama būstui. Struktūriniai darbo rinkos kaitos, taip pat demografinès struktūros pokyčiai lemia sudètingèjanti jaunesniujų kartu atstovu apsirūpinima būstu. Tyrèjai sutinka, kad vyresniosios generacijos būsto sektoriuje buvo labiau privilegijuotos ir savo laiku turëjo geresnes apsirūpinimo būstu galimybes. Straipsnyje siekiama atskleisti viduriniosios kartos (gimusiuju 1970-1984 m.) atstovu galimybiu konteksta apsirūpinant būstu Lietuvoje. Šia karta verta apibūdinti kaip atskira kohorta ir dèl menko tyrëju dèmesio, ir dèl aktyviuoju šeiminio gyvenimo periodu jos patirtos sparčios visuomenès kaitos bei struktūriniu ekonominiu ir politiniu sąlygu, iskaitant ir būsto politikos pokyčius. Šie aspektai skiria ja nuo vyresniuju, gyvenusiu sovietinès būsto aprūpinimo sistemos aplinkoje, ir jauniausiujų kartu, socializuotu liberalios ekonomikos ir dominuojančios privačios būsto nuosavybès sąlygomis.
\end{abstract}

Keywords: housing, housing policy, self-provision of housing, housing ownership, generation, middle generation, welfare state.

Raktažodžiai: būstas, būsto politika, apsirūpinimas būstu, būsto nuosavybè, karta, vidurinioji karta, gerovès valstybe .

\section{Ivadas}

Apsirūpinimas gyvenamuoju būstu - vienas iš esminių asmens poreikių ir reikšmingas kriterijus, apibrèžiantis asmens gerovę ir poziciją visuomenejje. Pastaraisiais metais būsto politikos klausimus analizuojantys Vakarų šalių ir Lietuvos tyrèjai daug dèmesio skiria jaunų namų ūkių apsirūpinimo būstu analizei (McKee, 2012; Forrest, Yip, 2013; Clapham et al., 2014; Brazienè et al., 2018; Brazienè, Mikutavičienè, 2018; Indriliūnaitè, Žilys, 2018; Brazienė, 2019). Jauni namų ūkiai, skirtingai nei jų tėvų ar senelių karta, šiandien susiduria su modernių būsto politikos sistemų kaitos, taip pat besitraukiančios gerovès valstybès ir finansų rinkų keliamais iššūkiais, todèl būsto nuosavybès ịgijimą nukelia vèlesniam laikui, t. y. ilgiau gyvena tėvų namuose ar būstą nuomojasi (Lennartz et al., 2016; Filandri, Bertolini, 2016). Tẻvų ekonominiai ištekliai bei turima būsto nuosavybė ilgainiui taip pat vis reikšmingiau apibrěžia jų vaikų galimybes būsto rinkoje (Lennartz, Helbrecht, 2018).

Skirtingų kartų atstovams atskirais jų gyvenimo etapais susiduriant su skirtingais konflikto šaltiniais materialinès gerovės užtikrinimo, užimtumo ir kitose srityse, daugelį šiandienos patiriamų 
socialinių ir ekonominių iššūkių galima įvardinti kaip „kartų problemas“(White, 2013). Vadinamoji „kartų analizès“ prieiga individo patirti leidžia vertinti ne vien iš individualistinès ,gyvenimo kelio“ perspektyvos (Coulter, Scott, 2015; Stone et al., 2014), tačiau ir atsižvelgiant ị išorines aplinkybes struktūrinius apribojimus (pavyzdžiui, ekonomines krizes ar politines reformas) bei galimybes (Woodman, Wyn, 2015). Jau 1952 m. K. Manmheimas teigè, kad kartos atstovų išgyventi reikšmingi ívykiai stipriai paveikia jos atstovus, todèl norint suprasti kartos išgyvenimus, svarbu analizuoti jos turimą patirti (Mannheim, 1952). Nors kartų analizès perspektyva nėra plačiai taikoma analizuojant skirtingų visuomenès grupių šiandien patiriamus socialinius ir ekonominius netolygumus Lietuvoje, vis dèlto tokia analizè padeda gilintis i vieno esminių asmens poreikių - būsto prieinamumo ir valstybès paramos ji įsigyjant - ypatumus. Vertinant skirtingų kartų galimybes siekiant būsto nuosavybės atkurtosios nepriklausomybès laikotarpiu, svarbu atsižvelgti ị intensyvią būsto politikos pertvarką, vykusią XX a. paskutiniajame dešimtmetyje, ir jos įtaką tolesnei šios srities politikos raidai bei būsto fondo struktūrai. Taip pat negalima eliminuoti ir išorinių šalies būsto politiką formavusių veiksnių, pvz.: finansų krizių, darbo rinkos politikos, demografinių visuomenès ar gerovès valstybės pokyčių (Aidukaitè et al., 2014).

Šio straipsnio tikslas - atskleisti viduriniosios kartos (gimusiujų 1970-1984 m.) atstovu apsirūpinimo būstu galimybių kontekstą Lietuvoje. Nors ši karta, kaip atskira kohorta, dar nėra sulaukusi didelio šalies tyrèjų dėmesio, tačiau jos išskyrimas yra vertingas dèl aktyviuoju šeiminio gyvenimo periodu patirtų sparčios visuomenès kaitos sąlygų. Intensyvi šalies būsto politikos pertvarka po nepriklausomybės atkūrimo 1990-aisiais, suformavusi dualistinès būsto sistemos tipą, suponavo tarpgeneracinès nelygybės situaciją tarp skirtingų kartų - vyresniosios, turèjusios sąlyginai lengvesnę prieigą prie būsto nuosavybès, ir viduriniosios kartos. Vyresnioji karta ịgijo pranašumą, masinès būstų privatizacijos laikotarpiu galèdama lengviau pasinaudoti valstybès parama ịsigyjant turimą būstą, tačiau jų vaikai, viduriniosios kartos atstovai, pateko ị neapibrèžtą situaciją apsirūpinimo būstu sprendimų paieška savarankiško gyvenimo pradžioje daugeliu atvejų teko patiems šios kartos atstovams ir jų šeimų nariams (Brazienė et al., 2018; Indriliūnaitė, Žilys, 2018). Dauguma šios kartos atstovų nebegalejo pretenduoti i privatizuojamą būstą dèl ịstatymo numatyta tvarka šia teise jau pasinaudojusių jų tèvų, o rinkoje susidūrẻ ne tik su būstų pasiūlos trūkumu, bet ir jų ịperkamumo problema.

Straipsnyje siekiama realizuoti šiuos uždavinius: (1) aptarti pagrindinius modernios būsto politikos kaitos bruožus ir skirtingų kartų apsirūpinimo būstu galimybių ypatumus, (2) pristatyti Lietuvos būsto politikos raidos ir būsto sektoriaus struktūros ypatumus atkurtosios nepriklausomybès laikotarpiu, (3) aptarti viduriniosios kartos apsirūpinimo būstu kontekstą ir galimybes aktyviuoju šeiminio gyvenimo periodu.

Rengiant straipsni taikyti šie tyrimo metodai: mokslinès literatūros ir teisinių dokumentų analizé, reprezentatyvios Lietuvos gyventojų, gimusių 1970-1984 m., anketinès apklausos $(\mathrm{N}=3005)^{1}$, atliktos $2019 \mathrm{~m}$. tiesioginio interviu būdu, duomenų statistinè analizè ir antrinių statistinių duomenų analizè.

Straipsnyje pristatoma, kaip kintantis modernus būsto politikos modelis ir mažèjantys gerovès valstybès įsipareigojimai gyventojams, aktyvi finansų sektoriaus ịtaka gyvenamojo būsto rinkoje keičia daugelio Vakarų visuomenių namų ūkių apsirūpinimo būstu praktikas bei išryškina tarpgeneracinius ir socioekonominius namų ūkių galimybių skirtumus. Remiantis teisinių dokumentų, pirminių ir antrinių statistinių duomenų analize antrojoje straipsnio dalyje aptariami Lietuvos būsto politikos ypatumai ir dabartinio būsto fondo formavimosi kontekstas atkurtosios nepriklausomybès laikotarpiu bei viduriniosios kartos apsirūpinimo būstu situacija ir galimybių scenarijai.

\footnotetext{
${ }^{1}$ Reprezentatyvi 34-48 metų amžiaus Lietuvos gyventojų apklausa (N=3005, iš kurių 1780 moterų ir 1225 vyrai) atlikta 2019 m., igyvendinant mokslo tyrimų projektą ,Šeimos, nelygybės ir demografiniai procesai“ (fin. Europos socialinio fondas (projekto Nr. 09.3.3-LMT-K-712 pagal dotacijos sutartị su Lietuvos mokslo taryba (LMT LT).
} 


\section{Modernios būsto politikos kaita ir namų ūkių apsirūpinimo būstu galimybès}

Atsižvelgiant ì valstybès dalyvavimo pobūdị būsto sektoriaus reguliaciniuose mechanizmuose, moderniose gerovès valstybėse būsto politika skiriama ị unitarines ir dualistines būsto sistemas. Unitarinèms sistemoms būdingas didesnis valstybinès gerovès sistemos dalyvavimas apsirūpinant būstu ir privataus bei socialinio būsto sektorių unifikavimas ị bendrą būsto fondą. Dualistinèse sistemose atsakomybę už būsto poreikius valstybė deleguoja patiems namų ūkiams, o dominuojantis privataus būsto fondas iš esmès yra kontroliuojamas privačių rinkos veikèjǔ. Ši sistema sukuria sąlygas būstui komodifikuoti - būstas tampa rinkos prekè (Kemeny, 1992, 1995; Žilys, 2018). Vis dèlto pastaraisiais dešimtmečiais stebimas gana ryškus posūkis link būsto politikos liberalizavimo tiek dualistinèse, tiek ir unitarinèse būsto sistemose. Jis pasireiškia mažèjančiais valstybès įsipareigojimais tenkinant apsirūpinimo būstu poreikius bei dẻl to augančiomis pačių gyventojų atsakomybėmis, didèjančia finansų sektoriaus ịtaka įvairinant finansinių produktų pasiūlą bei menkejjančiais valstybès reguliavimo svertais (Arbaci, 2007; Aidukaitè et al., 2014). Tokia būsto sektoriaus kaita - modernių būsto sistemų liberalizavimas - stebima daugelyje Vakarų šalių ir žymi skirtingų būsto politikos sistemų supanašèjimą (Ruopilla, 2005).

Šalių vyriausybės yra suinteresuotos skatinti igyti privačią būsto nuosavybę, nes taip taupo viešųjų paslaugų išlaidas bei siekia, kad namų ūkiai prisiimtų daugiau asmeninès atsakomybès už savo gerovę, o senatveje galètų pasinaudoti santaupomis, kurias gyvenimo eigoje akumuliuoja turima būsto nuosavybė (Druta, Ronald, 2016). Būsto nuosavybès igijimo aspiracijos išlieka pačių namų ūkių ekonominio saugumo garantas bei finansinès sèkmès atributas globaliame, nestabiliomis ir vis menkiau reguliuojamomis darbo rinkomis pasižyminčiame pasaulyje. Būsto nuosavybès turèjimas namų ūkiams taip pat leidžia išlaikyti pasiektą socialinę padètį bei padidinti apsaugą nuo asmeninių ir greitai kintančio išorinio pasaulio sukrètimų, taip išlaikant ontologinio saugumo jausmą (ColicPeisker, Johnson, 2010). Svarbu atkreipti dėmesị, kad šis politinis ir ideologinis būsto nuosavybès sureikšminimo diskursas sukuria ir nemažai įtampų. Būsto politikos tyrimai Vakarų šalyse atskleidžia, kad išaugusi individualių namų ūkių atsakomybe už apsirūpinimą būstu išryškina tarpgeneracinius ir socioekonominius namų ūkių skirtumus. Labiausiai šie skirtumai matomi lyginant vyresniųjų ir jaunujų kartų namų ūkių situacijas. Vyresniosios kartos savo laiku buvo labiau privilegijuotos, o dabartinès kartos dažniau susiduria su pažeidžiamumu siekdamos igyti būsto nuosavybę dèl augančių gyvenamojo būsto kainų ir jau minètos gerovès valstybès politikos pokyčių (Mckee, 2012; Ronald, Elsinga, 2012; Higgs, Gilleard, 2010). Šie procesai yra veikiami ir demografinių veiksnių - perèjimo ị suaugystę modelio pokyčių. Šiuolaikinio jaunimo, skirtingai nei jų tėvų kartos, perẻjimo ị suaugystę trajektorijos stipriai išsitęsia laike, igyja naujų formų, dinamikos, yra mažiau prognozuojamas. Todèl ir su suaugusiojo gyvenimu siejami tradiciniai atributai apsigyvenimas atskirai nuo tėvų, įsitvirtinimas darbo rinkoje, partnerystè arba santuoka - yra ịgyjami vèlesniame amžiuje (Buzar et al., 2005).

Pasak tyrimų, pastaraji dešimtmetị vis daugiau namų ūkių dualistinèse būsto sistemose patenka ì vadinamaji „,nuolatinès nuomos“ ciklą, kai, išaugus gyvenamojo būsto kainoms, jų galimybès pretenduoti ị būsto nuosavybę yra stipriai apribojamos. Besiformuojanti vadinamoji „,nuomininkų karta“, kuria Jungtinejje Karalysteje ir kitose dualistinès būsto sistemos šalyse ịvardijami jauni suaugusieji būsto nuomininkai, tyrejus skatina diskutuoti apie kartų būsto karjerų skirtumus, kai dabartinio jaunimo kelias link būsto nuosavybės yra ilgesnis, lyginant su jų tėvų karta (Doling, Elsinga, 2013; Lennartz, 2011, 2014).

Socioekonominius namų ūkių skirtumus, žyminčius nevienodas apsirūpinimo būstu galimybes, iliustruoja ir tarpgeneracinių perlaidų, siejamų su būsto sektoriumi, tyrimai, leidžiantys ịvertinti ryšį tarp tèvų būsto nuosavybès ir vaikams teikiamos paramos būstui. Tèvų turima būsto nuosavybė teikia jiems ekonomini pranašumą, leisdama sutaupytus būsto išlaikymo ekonominius resursus vẻliau perleisti vaikams, taip prisidedant prie jų apsirūpinimo būstu ar kompensuojant patiriamas finansines išlaidas paskoloms ar kitiems finansiniams būsto įsigijimo mechanizmams (Mulder, Smiths, 2013; Indriliūnaitè, 2019). Kartu ši praktika padeda palaikyti būsto kainų infliaciją, 
taip siaurindama būsto nuosavybès teisès prieinamumą tiems asmenimis, kurie neturi konkrečios tèvų, giminaičių ar kitų artimujų finansinès paramos. Šiuo aspektu tarpgeneracinis kokybiško būsto ir ypač būsto nuosavybès perdavimas iš kartos ị kartą stiprina kartų nelygybę (Mulder, 2007).

\section{Lietuvos būsto politikos ypatumai atkurtosios nepriklausomybės laikotarpiu}

Vienas reikšmingiausių modernios Lietuvos būsto politikos raidos bruožų - būsto sistemos pertvarka, ịvykusi šalies nepriklausomybès atkūrimo pradžioje, - perèjimas iš planinès aprūpinimo būstu sistemos ị rinkos mechanizmais grindžiamą apsirūpinimą (Brazienė et al., 2018; Indriliūnaitė, Žilys, 2018). Iki 1990-ųų metų Rytų ir Vidurio Europos šalyse veikęs išteklių paskirstymo kontrole grịstas būsto politikos modelis pasižymèjo rinkos mechanizmų subordinacija ir biurokratiniu valdymu (Hegedüs, Lux, Teller, 2013; Tsenkova, 2000). Staigūs transformacijos procesai išryškino šio modelio ydas, pavyzdžiui, būstų paskirstymą atsižvelgiant ị nuopelnus, planinio organizavimo nulemtą prastą būsto kokybę bei realiomis sąnaudomis nepagrịstus jų išlaikymo kaštus, šalia centralizuotos būsto sistemos egzistavusią neformaliąą rinką.

1992 m. valstybès parengta programa „Būstas“ buvo siekiama pakeisti iki tol egzistavusias sovietines plačios aprèpties būsto programas bei ịsipareigojimus už gyventojų būsto poreikius, kartu sukuriant privačios būsto rinkos pamatus (Žin., 1992-09-30, Nr. 27-791; Brazienè etal., 2018). Minimi privatizacijos ir nuosavybès atkūrimo procesai skatino gyventojus veikti. Spaudimą generavo tiek atsivèrusios galimybès, tiek ir tvyrojęs pokyčių nerimas, todèl daugelis piliečių ịstatymo numatyta tvarka skubejjo teikti prašymus, siekdami būsto nuosavybės (Hegedüs, Teller, 2006). Skelbiama, kad Lietuvoje $1991 \mathrm{~m}$. ịsigaliojus LR butų privatizavimo ịstatymui (1991), didžioji dalis atitinkančios kriterijus būsto nuosavybès buvo privatizuota iki $1993 \mathrm{~m}$. pabaigos, o jau $1996 \mathrm{~m}$. pradžioje buvo patenkinti 94 proc. gyvenamojo būsto privatizacijos prašymų (Estonia, Latvia, and Lithuania, 1995; Burinskienè, 1998). Vis dèlto pirmaji atkurtosios nepriklausomybès dešimtmetị vykusi intensyvi būstų privatizacija vertinama nevienareikšmiškai. Nors minètas butų privatizavimo ịstatymas gyventojams sudarè galimybę išsipirkti valstybės valdomus būstus ir ịgyti galimybę jais laisvai disponuoti, ne visi asmenys tuo metu turejo vienodas galimybes privatizuoti gyvenamuosius būstus, jų pradinès pozicijos buvo skirtingos (Burinskienè, 1998, 296). Pavyzdžiui, viena būstų privatizavimo sąlygų: asmenys iki $1989 \mathrm{~m}$. lapkričio 3 d. turèjo nuolat gyventi Lietuvos Respublikos teritorijoje ir įstatymo ịsigaliojimo dieną būti perkamo gyvenamojo būsto nuomininkai ar jų šeimų nariai. Be to, pagal galiojusi įstatymą, viena šeima galèjo privatizuoti tik vieną butą (Žin., 1991-0620, Nr. 17-449).

İvykusi būstų privatizacija lèmè ir didelius būsto fondo struktūros pokyčius. $1989 \mathrm{~m}$. Lietuvos gyventojų ir būstų surašymo duomenimis, „būstuose, kurie priklausė valstybinėms, kooperatinėms, visuomeninėms organizacijoms ir gyvenamujų namų kooperatyvams gyveno 69,1 proc. gyventojų, o nuosavus būstus turejo tik 30,9 proc. gyventojų, tuo tarpu $2001 \mathrm{~m}$. surašymo metu jau 95,2 proc. gyventojų gyveno nuosavame būste. Taigi, per 12 metų nuo nepriklausomybès atkūrimo iš esmès pasikeitè gyvenamujų būstų nuosavybès forma“" (Lietuvos statistikos departamentas, 2003, 3).

Aptariama transformacija skatino dualistinès būsto sistemos tipo, pasižyminčio ribotu valstybès vaidmeniu apsirūpinant būstu, įsitvirtinimą Lietuvoje ir kitose posovietinèse šalyse. Tuo būdu valstybès atsakomybè iš esmès koncentruojama tik ị vadinamaji likutinị socialinio būsto sektorių. Lietuvoje ir kitose Rytų Europos šalyse šis sektorius patrauklumą prarado intensyvios būstų privatizacijos metu, kai juo naudojosi namų ūkiai, neturèję galimybių ịgyti turimo būsto (Hegedüs, Teller, 2006). Ilgainiui šis sektorius tapo problemiškas dèl jame ,istrigusių“ mažas pajamas generuojančių namų ūkių su pažeidžiamiausiomis gyventojų grupėmis (Hegedüs, Lux, Teller, 2013, 13). Socialinio būsto gyventojų mokama nuoma ịprastai nepadengia šio būsto išlaikymo, todèl už socialinių būstų nuomą atsakingos šalies savivaldybès susiduria su sunkumais plètojant ši būsto fondą. Ši problema implikuoja ir vieną pagrindinių socialinio būsto sektoriaus infrastruktūros trūkumų - prastą šių būstų kokybę, kuri dar labiau marginalizuoja šio sektoriaus gyventojų padètị (Tosics, Hegedüs, 1996; Indriliūnaite, 2018). Nuomininkų statusas, aiškiai neapibrèžtas gyvenimo 
socialiniame būste laikotarpis, dažnai problemų kelianti kaimynystė šio būsto gyventojų taip pat neskatina rūpintis būstu bei patiems investuoti ị gyvenamosios aplinkos kokybę.

Pereinamuoju laikotarpiu šalyje susiformavęs dominuojantis privataus būsto sektorius su likutine socialine nuoma programuoja ribotus gyventojų pasirinkimus. Atkurtosios nepriklausomybės pirmajji dešimtmetị buvusi ženklų gyvenamojo būsto trūkumą keičia ribotas jo prieinamumas, tampantis itin aktualus didžiuosiuose šalies miestuose (Tsenkova, 2000, 132). Šioje situacijoje labiausiai pažeidžiami tampa tie namų ūkiai, kuriems dèl ekonominių ar kitų priežasčių sudètinga siekti būsto nuosavybès, tačiau kartu jie neatitinka specifinių ir realią ekonominę situaciją ne visada atliepiančių valstybės remiamo socialinio būsto skyrimui keliamų reikalavimų. Taip šie namų ūkiai yra stumiami ị neformaliają privačios būstų nuomos rinką, kuri, kaip rezidencijos forma, šalyje nėra aiškiai reglamentuota. Privati būsto nuoma pirmiausia yra traktuojama kaip ekonominè veikla, todėl nemažai erdvės yra pačių asmenų - nuomotojo ir nuomininko - neformalių susitarimų sričiai. Kaip rodo 2017-2018 m. Lietuvoje atlikta reprezentatyvi jaunų (18-35 m. amžiaus) asmenų anketinė apklausa, 45 proc. nuomininkų nebuvo sudarę nuomos sutarties ir tik 24 proc. jų nuomojamame būste buvo deklaravę gyvenamają vietą (Indriliūnaitè, Žilys, 2018). Nesant aiškiai ịteisintų privačią nuomą, kaip rezidencijos formą, apibrèžiančių sąlygų, o valstybei pasilikus menkus svertus šio būsto sektoriaus kontrolei, toks būstas dažniausiai negarantuoja saugios ir nuolatinès rezidencijos, būsto nuomininkai patiria daugiau nesaugumo dèl ekonominès priklausomybès nuo nuomotojų ir jų keliamų sąlygų.

\section{Viduriniosios kartos apsirūpinimo būstu galimybès}

Trumpai aptarta šalies būsto politikos situacija atkurtosios nepriklausomybès laikotarpiu išryškina, kad vidurinioji karta, skirtingai nei jų tẻvai, privatizacijos laikotarpiu turèję sąlyginai lengvesnę prieigą prie būsto nuosavybès, susidūrè su sudètingesne apsirūpinimo būstu situacija. Viduriniajai kartai teko ne tik besiformuojančios liberalios būsto politikos keliami iššūkiai, bet ir sovietiniais laikais ir pirmaisiais atkurtosios nepriklausomybès dešimtmečiais buvusi itin aktuali būsto trūkumo problema. Nors paskutiniais sovietinès industrinès visuomenès gyvavimo metais, vykstant ūkio pertvarkai, ėmè laisvèti iki tol griežtai ribojama individualių būstų statyba, susidariusio būsto trūkumo ji neišsprendè (Žilys, 2019, 26 p.). Nuo 1991 metų panaikinus individualių namų dydžio ribojimus ir liberalizavus statybos tvarką, gyventojai pradejo statyti didelius individualius namus, tačiau sparčiai didèjant jų išlaikymo kaštams, ilgainiui jie tapo nepaklausūs (Teisès aktų, reglamentavusių teritorijų planavimo, 2009, 15 p.).

Statybų plètra pirmaisiais atkurtosios nepriklausomybès dešimtmečiais Lietuvoje pasižymėjo netolygumais. 1992-2002 m. nekilnojamo turto rinka buvo labiau orientuota i prekybos centrų bei daugiafunkcinių pastatų statybą, o gyvenamajam būstui dėmesio teko mažiau dèl aukštesnio komercinio nekilnojamojo turto pelningumo ir lengviau prognozuojamų veiklos sąlygų (Ivanauskas et al., 2008, 273). Nuosaikiai augęs statybų mastas, apie 1997-1998 m. nuslopo tiek dèl Rusijos ekonominès krizès ir sumažejusių gyventojų pajamų, tiek dèl Lietuvos vidaus valdymo problemų, ribotos statyboms skirtų sklypų pasiūlos bei neišspręstų žemės nuosavybės teisių atkūrimo klausimų. Pereinamojo laikotarpio pradžioje, 1990 metais, buvo pastatyta 22100 naujų būstų, bet 2002 metais - tik 4562 būstai. Vadinasi, per metus pastatyti nauji būstai sudarè 0,3 procento viso būsto fondo, tačiau ES šių rodiklių vidurkis tuo metu buvo 1,5 procento. Būstų rinką $1998 \mathrm{~m}$. šalyje šiek tiek suaktyvino lengvatinių paskolų suteikimo politika, siejama su augančiu Lietuvos ịsitraukimu i pasaulinę rinkos ekonomiką. Šie procesai turèjo įtakos daugiabučių namų funkcinei struktūrai pagrindinę daugiabučių namų masę sudarè maži 35-50 kvadratinių metrų butai (Gerdvilis, 2012, 69 p.).

Bendrai šalyje toliau išliekant gyvenamojo būsto trūkumo problemai, būsto stygius 2002 metais siekė 7 procentus, o Vakarų ar Šiaurès Europos valstybėse šis rodiklis svyravo apie 2 procentus. Tais pačiais metais Lietuvoje 1000 gyventojų teko 367 butai, o aukščiau minètose valstybėse - apie 450 ir būsto naudingasis plotas vienam gyventojui sudare atitinkamai 22,1 ir 30 kvadratinių metrų. Pagal vienam gyventojui tenkanti gyvenamajji plotą Lietuva atsiliko ir nuo 
kaimyninių valstybių - Latvijos bei Estijos. Žemą Lietuvos būstų rinkos išsivystymo lygi šalyje rodè ir mažiausia paskoloms būstui tenkanti dalis lyginant su BVP, taip pat būsto paskolos dydis, tenkantis vienam gyventojui (Dževeckytė, 2004; Žin., 2004-01-24, Nr. 13-387).

2004 m. Lietuvai tapus Europos Sajungos ir NATO nare, didžiuosiuose šalies miestuose suaktyvėjo daugiabučių statyba, tačiau galimybę ịsigyti šiuos būstus ribojo santykinai žema gyventojų perkamoji galia ir nuo 2002-uјų iki 2005-ujų metų vidutiniškai 30-50 proc. išaugusios nekilnojamojo turto kainos (2005 m. pasiekus piką, vidutinis butų kainų indekso metinis pokytis didžiuosiuose šalies miestuose siekè 50 proc., o kai kuriuose segmentuose - net 120 proc.) (Ivanauskas et al., 2008, 274). Kaip rodo to meto statistiniai duomenys, „būsto daugiabučiame name vidutinè kaina $2004 \mathrm{~m}$. Lietuvoje buvo 8 kartus didesnè nei vidutinès namų ūkių grynosios metinès pajamos, o naujų individualių namų vidutinè kaina - net 20 kartų didesnè. Tuo metu šis santykis ES valstybėse senbuvėse buvo ne didesnis kaip 4-5 kartai“ (Žin., 2004-01-24, Nr. 13-387, 8). Nepaisant šių skirtumų buvo stebima auganti būstų paklausa. Šis realaus ekonomikos ir perkamosios galios augimo neatitinkantis butų paklausos bumas buvo siejamas su bendru Lietuvos ekonominiu augimu bei augančiais gyventojų pajamų lūkesčiais, taip pat ir su gana palankiomis būsto paskolų sąlygomis. To meto ribotos paklausaus turto pasiūlos nulemtas kainų augimas neatsvèrè paklausos bumo. Rinkos suaktyvejjimą ir perkaitimą lèmė ir subjektyvios priežastys. Gyventojai baiminosi, kad Lietuvai įstojus ị ES, būsto kainos dar labiau išaugs ir būstas taps apskritai sunkiai ịperkamas. Nemažą ịtaką turejo ir ịvairių finansinių institucijų, tarpusavyje kovojančių dèl klientų, spekuliacijos, siūlant ivvairias nuolaidas ir akcijas bei viešojoje erdveje tvirtinant, kad kainų augimas racionalus ir tvarus, taip pat ir išaugę gyventojų aukštesnio pragyvenimo lygio lūkesčiai (Dževeckytė, 2004). Iš esmès labiausiai su minètomis subjektyviomis priežastimis, o ne su išaugusia gyventojų perkamaja galia siejamas ir ženklus metinis kainų kilimas: 2004 m. 10-20 proc. naujos statybos būstuose ir net 30-40 proc. senesniuose blokiniuose namuose (statytuose iki $1980 \mathrm{~m}$. miegamuosiuose rajonuose). Kaimyninèse šalyse (Latvijoje, Estijoje), kurios tuo metu taip pat rengèsi tapti ES narèmis, tokiu didelių būstų kainų šuolių nebuvo stebima, ten kainos pakilo 5-15 proc. (Dževeckytė, 2004). Skelbiama, kad $2005 \mathrm{~m}$. pabaigoje paskolas būstui ịsigyti turèjo 6 proc. namų ūkių, finansavimą bankai suteikdavo devyniems iš dešimties rinkoje sudaromų sandorių, o tais pačiais metais bankų suteiktos būsto paskolos didèjo 86,5 proc. (Belinskaja, Rutkauskas, 2007, 22).

2007 m. būsto kainos pasiekè aukščiausią lygi, tačiau tada ėmè kristi. Nuo 2007 m. iki 2010 m. būstų kainų indeksas krito 45 proc. 2009 m. perpus sumažèjo ir leistų statyti butų skaičius, buvo siekiama parduoti jau pastatytus butus. Nors pagal Lietuvos banko apskaičiuojamą būsto ịperkamumo indeksą $2008 \mathrm{~m}$. gyventojų galimybès ịsigyti būstą ženkliai pagerẻjo, tačiau $2009 \mathrm{~m}$. šalyje žymiai išaugęs nedarbas ir sumažějęs darbo užmokestis sunkino gyventojų galimybes skolintis būsto ịsigijimui (Finansinio stabilumo apžvalga, 2010, 64). Didžiają paskolos gavèjų dalị sudarè aukštesnes pajamas gaunantys, išsilavinę, kvalifikuoti specialistai, vadovai, sunkmečiu išlaikę darbo vietas (Verslo žinios, 2010). Jie, bankų analitikų duomenimis, pirko ekonominès-vidutinès klasės butus, o nuosavus būstus jau turintys asmenys, siekiantys pagerinti gyvenimo sąlygas, pirko naujesnès statybos būstus arba namus. Vèlesniais metais fiksuotas tvarus būsto kainų augimas ypač didžiuosiuose šalies miestuose buvo siejamas su augančiomis gyventojų pajamomis (Finansinio stabilumo apžvalga, 2015).

Aukščiau minètos būsto rinkos tendencijos atsispindi ir 2019 m. reprezentatyvios Lietuvos gyventojų, gimusiujų 1970-1984 m., apklausos $(\mathrm{N}=3005)$ rezultatuose apie dabartinio gyvenamojo būsto ịsigijimą. Didžiausia vyriausiųų viduriniosios kartos atstovų (44-48 m. amžiaus asmenų (namų ūkių)) dalis, kurių savarankiškas debiutas būsto sektoriuje vyko pirmajame atkurtosios nepriklausomybès dešimtmetyje, teigè, kad dabartinį gyvenamaji būstą yra paveldèję iš tèvų, giminaičių ir artimujjų - 41,4 proc. $(\mathrm{N}=728)$. Didžiausia jaunesniujjų viduriniosios kartos atstovų (34$38 \mathrm{~m}$. amžiaus asmenų (namų ūkių)) dalis nurodè, kad dabartini gyvenamaji būstą dažniau įsigijo paskolos, kuri dar yra grąžinama, lèšomis - 37 proc. $(\mathrm{N}=293)$, o mažesnioji - sumokant visą kainą ar jị paveldèjo iš tèvų ar artimujjų (žr. 1 pav.). 


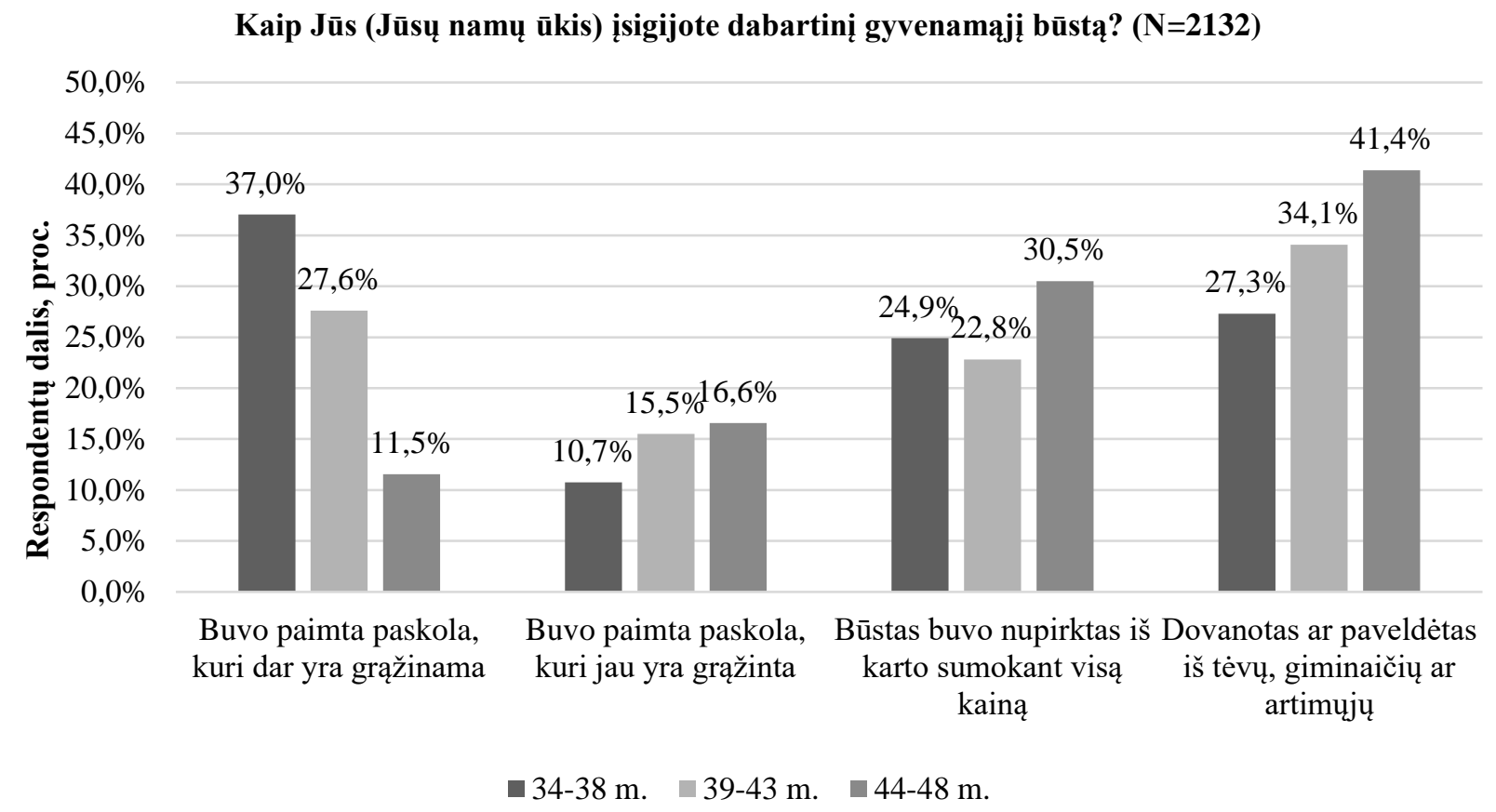

* Egzistuoja statistiškai reikšminga priklausomybe $\left(\chi^{2}(6, N=2132)=141,399 ; p<0,001\right)$ ir statistiškai reikšmingas silpnas ryšys $(V=0,182 ; p<0,001)$.

\section{Pav. 1. Dabartinio gyvenamojo būsto ịsigijimo situacija}

Šaltinis: sudaryta autorès.

Šios tendencijos atliepia aukščiau minètus šalies būsto politikos raidos ypatumus - didelị būstų trūkumą ir sudètingas galimybes jị ịpirkti dèl menkų atlyginimų pirmaji šalies atkurtosios nepriklausomybès dešimtmetị bei maždaug nuo antrojo dešimtmečio ir vèliau pradèjusią augti privataus būsto rinką, išplètusią tiek pačių būstų, tiek ir finansinių produktų jiems ịsigyti (paskolų ir pan.) pasiūlą. Pastaroji didžiaja dalimi vis dèlto buvo pasiekiama tik aukštesnio išsilavinimo ir aukštesnių pajamų namų ūkiams. Minèto tyrimo duomenys atskleidžia, kad aukštajį universitetinị išsilavinimą turintys asmenys dažniau nurodė, kad dabartinị gyvenamajị būstą ịsigijo paèmę banko paskolą (41,6 proc.) arba nusipirko jị sumokant visą kainą $(25,5$ proc.) nei paveldèjo ar būstą gavo dovanų iš tèvų ar artimujų (16,9 proc). Profesinị be vidurinio arba žemesnị nei vidurinị išsilavinimą turinčių asmenų grupejje dabartinio būsto ịsigijimo su paskola dalis sudarè 11,6 proc., o tẻvų, giminaičių ar artimųjų padovanoto ar paveldèto būsto įsigijimo dalis - 31,6 proc.

Tyrimo metu išryškejjusios viduriniosios kartos atstovų būsto įsigijimo tendencijos atliepia ir Europos gyvenimo kokybės tyrimo duomenis, rodančius išaugusị būsto nuosavybės ịsigijimą, naudojantis finansiniais mechanizmais: atitinkamai $2007 \mathrm{~m}$. nuosavą būstą su paskola nurodè įsigiję 3 proc. $35-49 \mathrm{~m}$. amžiaus šalies gyventojų, o $2016 \mathrm{~m}$. šis skaičius išaugo iki 19 proc. Atitinkamai mažèjo nuosavo būsto įsigijimo be paskolos dalis: $2007 \mathrm{~m}$. būstą be paskolos įsigijo 87 proc. minèto amžiaus gyventojų, nors 2016 m. šis skaičius mažejo iki 66 proc. (European Quality of Life Survey, 2007, 2016). Kartu EU-SILC (2016) duomenys rodo nuosavame būste gyvenančių asmenų skaičiaus mažėjimo tendencijas Lietuvoje: 2008 m. nuosavame būste gyveno 92,2 proc., o 2016 m. - 90,3 proc. šalies gyventojų. Ženklesnis kritimas fiksuojamas tarp mažesnes pajamas turinčių gyventojų (Bobinaite et al., 2019, 99).

Nagrinejjamu laikotarpiu valstybès parama apsirūpinant būstu iš esmès apsiribojo socialinio būsto sektoriumi, skirtu ekonomiškai ir socialiai pažeidžiamiausių visuomenès grupių atstovams. Tiesa, pereinamuoju laikotarpiu ị poreikị paramai apsirūpinant būstu buvo sureaguota gana greitai dar 1992 m. priimtas Lietuvos Respublikos gyventojų apsirūpinimo gyvenamosiomis patalpomis i̊statymas, igalinęs savivaldybes socialiai remtiniems asmenims pirmumo teise išnuomoti turimas 
gyvenamąsias patalpas (Žin., 1992-05-20, Nr. 14-378). Ši tvarka veikè iki 2003 m. ịsigaliojusios naujos Lietuvos Respublikos valstybès paramos būstui ịsigyti ar išsinuomoti ịstatymo ịgyvendinimo įstatymo redakcijos, detaliau apibrèžusios savivaldybės socialinio būsto fondo sudarymo sąlygas ir šio būsto nuomos tvarką bei išplètusios tikslinių grupių sąrašą. Juo remiantis, ị socialinį būstą galèjo pretenduoti jaunos šeimos (kuriose abu sutuoktiniai yra ne vyresni nei 35 metų arba vienas asmuo tèvas arba motina vienas augina vaiką ir yra ne vyresnis (-è) kaip 35 metų), našlaičiai ir likę be tėvų globos asmenys, neiggalieji asmenys, socialinio būsto nuomininkai, turintys teisę ì būsto sąlygų pagerinimą, o taip pat buvo sudaroma eilè kitiems asmenims, nepatenkantiems į aukščiau minètas kategorijas (benamiams ir pan.) (Žin., 2002-12-06, Nr. 116-5189).

2015 m. ịsigaliojęs Lietuvos Respublikos paramos būstui ịsigyti ar išsinuomoti ịstatymas išplète tikslinę šios sistemos grupę - būsto parama nuo šiol gali būti skiriama nediferencijuojant mažas pajamas gaunančių asmenų (šeimų) pagal jų galimybes susirasti būstą ${ }^{2}$ (TAR, 2014-10-30, Nr. 15180). Tačiau ịstatyme numatyta labai žema pajamų kartelė ženkliai riboja gyventojų grupę, kuri gali pasinaudoti minèta valstybès parama. Pastaraisiais metais šalyje inicijuoti papildomi paramos būsto ịsigijimui regionuose jaunoms šeimoms (iki $35 \mathrm{~m}$. amžiaus) mechanizmai, apibrèžti 2018 m. ịsigaliojusiame Lietuvos Respublikos finansinès paskatos pirmąị būstą ịsigyjančioms jaunoms šeimoms ịstatyme (TAR, 2018-06-26, Nr. 10518), yra ne tik mažos apimties, tačiau ir nebeatliepia viduriniosios kartos apsirūpinimo būstu poreikio ir dèl amžiaus ribojimų.

Apibendrinant galima teigti, kad viduriniosios kartos atstovai savarankiško gyvenimo pradžioje spręsdami apsirūpinimo būstu klausimus susidūrė su labai skirtingomis problemomis nei daugumos jų tẻvai. Pastarųjų apsirūpinimo būstu klausimai sovietiniu laikotarpiu buvo griežtai reguliuojami valstybès institucijų, o pirmaisiais šalies nepriklausomybės atkūrimo metais didžioji dauguma jų igijo galimybę privatizuoti turimą šeimos būstą. Vidurinioji karta patyrè ne tik besiformuojančio naujojo šalies būsto politikos modelio keliamus iššūkius, bet ir kitų, su šiais klausimais susijusių sričių - gyvenamojo būsto trūkumo atkurtosios nepriklausomybès pradžioje, Rusijos ekonominès krizès metu ir po jo išaugusio didelio nedarbo, menkų atlyginimų sukeltų problemų - padarinius. Susiformavęs dualistinis būsto politikos sistemos modelis numato tik ribotą valstybės paramą gyventojų apsirūpinimo būstu srityje, todèl didžioji dauguma tiek vyresniųųu, tiek ir jaunesniųų viduriniosios kartos atstovų apsirūpinimo būstu klausimus sprendẻ kliaudamiesi tėvų, giminaičių ir artimujų parama bei savomis jëgomis. Vyresnieji šios kartos atstovai dèl būsto rinkoje susiklosčiusios situacijos jų savarankiško gyvenimo pradžioje - menkos būstų pasiūlos, aukštų jų kainų ir gaunamų mažų pajamų - ši klausimą dažniau sprendè pasitelkdami tẻvų šeimos turimus socialinius ir ekonominius resursus. Jaunesnieji kartos atstovai turèjo daugiau alternatyvų: igijo galimybę kliautis ne tik tèvų ir artimujų parama, tačiau pasinaudoti ir antrajame atkurtosios nepriklausomybès dešimtmetyje jau plačiau prieinamais bankų siūlomais finansiniais mechanizmais, skirtais apsirūpinti gyvenamuoju būstu. Vis dẻlto šie finansiniai produktai - ribota alternatyva, kadangi daugeliu atvejų nėra prieinami žemesnio išsilavinimo ir mažesnių pajamų namų ūkiams. Aptartos viduriniosios kartos apsirūpinimo gyvenamuoju būstu tendencijos iliustruoja ir atkurtosios nepriklausomybès laikotarpiu šalyje ịvykusius būsto politikos sistemos ir būsto prieinamumo pokyčius: pirmaisiais dešimtmečiais buvo susidurta su būsto trūkumo problema, tačiau vèliau - su prieinamo būsto trūkumo problema ir augančiomis nelygybèmis siekiant ịsigyti pirmajị būstą bei vis reikšmingesniu tèvų šeimos ir giminaičių bei artimujų paramos vaidmeniu siekiant būsto nuosavybès.

\section{Išvados}

1. Pastaraisiais dešimtmečiais vykstantys globalūs modernių būsto politikos sistemų liberalizacijos procesai žymi mažèjanti gerovès valstybès ir jos namų ūkiui teikiamos apsaugos

\footnotetext{
${ }^{2}$ Teisè ị paramą socialiniam būstui minėtame įstatyme apibrěžiama šioms gyventojų kategorijoms: ,jaunoms šeimoms, kuriose abu sutuoktiniai yra ne vyresni nei 35 m.; šeimoms, auginančioms tris ir daugiau vaikų (įvaikių); našlaičiams ir likusiems be tèvų globos asmenims; neigaliesiems ar šeimoms, kuriose yra neigalių asmenų; bendroji eilè (kitiems asmenims)““(TAR: 2014-10-30, Nr. 15180)
} 
vaidmenį bei spaudimą būstu rūpintis patiems namų ūkiams. Nors būsto nuosavybė tiek ideologiškai, tiek ekonominiu atžvilgiu ilguoju laikotarpiu laikoma saugiausia būsto forma, jos prieinamumas pastaraisiais dešimtmečiais pasidarè sudètingesnis tiek dèl išaugusių nekilnojamojo turto kainų, privačių rinkos veikèjų dominavimo sektoriuje ir menkesnio valstybès dalyvavimo reguliuojant šiuos procesus, tiek dẻl globalizacijos padarinių bei struktūrinių darbo rinkos pokyčių. Minètos priežastys lemia, kad dabartinès, būsto rinkoje debiutuojančios kartos yra mažiau privilegijuotos nei vyresniosios.

2. Lietuvos būsto sektoriaus pertvarka nepriklausomybès atkūrimo pradžioje, t. y. perèjimas iš planinès aprūpinimo būstu sistemos ị rinkos mechanizmais grindžiamą modelį, lèmè skirtingų kartų atstovų galimybių apsirūpinti būstu skirtumus. Transformacijos metu susiformavęs dualistinès būsto sistemos tipas, pasižymintis menkais valstybès reguliaciniais mechanizmais privataus būsto sektoriuje ir ribota socialine parama, lèmè, kad viduriniosios kartos atstovai, skirtingai nei jų tèvai, tureję galimybę pasinaudoti valstybès suteikta teise privatizuoti turimą šeimos būstą, patys tapo atsakingi už apsirūpinimą būstu.

3. Viduriniosios kartos atstovų savarankiškam debiutui apsirūpinant būstu sutapus su intensyviu transformaciniu laikotarpiu šalyje, jų būsto nuosavybės siekimo scenarijai buvo lemiami tiek ịvairių trikdžių sektoriuje (pvz., būsto pasiūlos trūkumo, aukštų būsto kainų), tiek ir finansinių krizių sukeltų pokyčių darbo rinkoje, darbo vietų trūkumo, menko atlyginimo bei iš to kylančių ekonominių sunkumų. Itin riboti valstybės paramos mechanizmai daugeliu atvejų neamortizavo namų ūkių patiriamų sunkumų ir neatliepe jų apsirūpinimo būstu poreikių.

4. Vyresnieji viduriniosios kartos atstovai, kurių savarankiškas debiutas būsto rinkoje ịvyko pačiu sudètingiausiu šalyje besiformuojančios naujos būsto sistemos laikotarpiu - pirmajị atkurtosios nepriklausomybès dešimtmetį - apsirūpinimo būstu klausimus iš esmès sprendè tèvų šeimos turimais resursais, o tokių neturintys arba naudojosi laikino būsto (pvz., privačios nuomos) rinka, arba ilgiau liko gyventi su tèvais. Jaunesnieji viduriniosios kartos atstovai, spręsdami ši klausimą, jau turèjo daugiau alternatyvų ir galejo veikti autonomiškiau - kliautis ne tik tèvų šeimos parama, bet ir, esant galimybei, pasinaudoti ịvairiais rinkos dalyvių siūlomais finansiniais skolinimosi įrankiais. Tiesa, šie, esant menkam valstybès reguliavimui, iš esmès yra prieinami tik aukštesnio išsilavinimo ir aukštesnių pajamų namų ūkiams. Likusieji namų ūkiai, kaip ir aukščiau minètu atveju, yra stumiami ị privačios būsto nuomos rinką ar dalinimąsi gyvenamuoju būstu su tėvais ar giminaičiais.

\section{Pastabos}

Šis straipsnis parengtas igyvendinant projektą „Šeimos, nelygybės ir demografiniai procesai“, kuris bendrai finansuotas iš Europos socialinio fondo lèšų (projekto Nr. DOTSUT - 09.3.3-LMT-K712-01-0020 pagal dotacijos sutartị su Lietuvos mokslo taryba (LMT LT)).

\section{Literatūra}

1. Aidukaitè, J., Lipnevič, A., Nefas, S., Narkevičiūtè, A., Anulytė, F. Būsto politika ir visuomenés iniciatyvos mieste. Vilnius: Lietuvos socialinių tyrimų institutas, 2014.

2. Arbaci, S. Ethnic Segregation, Housing Systems and Welfare Regimes in Europe. International Journal of Housing Policy, 2007, Vol. 7, No 4, 401-433.

3. Belinskaja, L., Rutkauskas, V. Būsto kainų burbulo sprogimas - problemos vertinimas. Ekonomika, 2007, 79, 7-27.

4. Bobinaitè, V., Galinis, A., Lekavičius, V., Miškinis, V., Neniškis, E., Norvaiša, E., Pažėraitè, A. Gyventoju galimybès apsirūpinti būstu ir priemonès būsto prieinamumui didinti. Rankraštis. Mokslo studija. Kaunas: Lietuvos energetikos institutas, 2019.

5. Brazienè, R. Lietuvos jaunimo apsirūpinimas būstu: patirtys ir požiūriai, Filosofija. Sociologija, 2019, T. 30, Nr. 2, 108-115. 
6. Brazienè, R., Mikutavičienè, I. Būsto politikos vertinimas Lietuvoje: jaunimo grupès požiūris, Viešoji politika ir administravimas, 2018, 17(3), 470-483.

7. Brazienè, R., Žilys, A., Indriliūnaitè, R., Mikutavičienè, I. Jaunimas ir būstas Lietuvoje: skirtingos galimybès, trajektorijos ir išš ükiai. Kaunas: Vytauto Didžiojo universitetas, 2018.

8. Burinskienè, M. Government Assistance Program in the Housing Sector in Lithuania. Facilities, 1998, Vol. 16, No.11, 295-301.

9. Buzar, S., Ogden, Ph. E., Hall, R. Households Matter: The Quiet Demography of Urban Transformation. Progress in Human Geography, 2005, 29 (4), 413-436.

10. Clapham, D., Mackie, P., Orfors, S., Thomas, I., Buckley, K. The Housing Pathways of Young People in the UK. Environment and Planning A: Economy and Space, 2014, Vol. 46, No 8, 2016-2031.

11. Colic-Peisker, V., Johnson, G. Security and Anxiety of Homeownership: Perceptions of Middle-class Australians at Different Stages of their Housing Careers. Housing, Theory and Society, 2014, 27(4), 351-371.

12. Coulter, R., Scott, J. 2015. What Motivates Residential Mobility? Re-examining self-reported Reasons for Desiring and Making Residential Moves. Population, Space and Place, 21(4), 354-371.

13. Doling, J., Elsinga, M. Demographic Change and Housing Wealth: Homeowners, Pensions and Asset-based Welfare in Europe. Dordrecht, Netherlands: Springer Link. 2013.

14. Druta, O., Ronald, R. Young Adults' Pathways into Homeownership and the Negotiation of Intra-family Support: A Home, the Ideal Gift“. Sociology, 2016, 51 (4), 783-799.

15. Dževeckytè, R. İsisiautèjusi butų kainų amplitudè mažès. Verslo žinios. 2004-01-28. https://www.vz.lt/archive/news.php/id=213798\&dCkzZ [2020-03-05].

16. Estonia, Latvia, and Lithuania: country studies. W. R. Iwaskin (ed.). Washington, D.C.: Federal Research Division Library of Congress. 1995.

17. European Quality of Life Survey 2007. https://www.eurofound.europa.eu/data/europeanquality-of-life-survey-2007 [2019 1105$]$.

18. European Quality of Life Survey 2016. https://bit.ly/2WVHprR [2019-11-05].

19. Filandri, M., Bertolini, S. Young People and Home Ownership in Europe. International Journal of Housing Policy, 2016, Vol. 16, No 2, p. 144-164.

20. Finansinio stabilumo apžvalga 2010. Vilnius, Lietuvos bankas. 2010. https://www.lb.lt/uploads/publications/docs/fsa_2010.pdf [2020-03-05].

21. Finansinio stabilumo apžvalga 2010. Vilnius, Lietuvos bankas. 2010. https://www.lb.lt/uploads/publications/docs/fsa_2015.pdf [2020-03-05].

22. Forrest, R., Yip, N. M. Young People and Housing: Transitions, Trajectories and Generational Fractures. London: Routledge. 2013.

23. Gerdvilis, V. Daugiabučiu funkcinès struktūros raida Lietuvoje. Vilniaus Gedimino technikos universitetas. Vilnius. Technika. 2012.

24. Hegedüs, J., Lux, M., Teller, N. Social Housing in Transition Countries. New York: Routledge. 2013.

25. Hegedüs, J., Teller, N. Managing Risks in the New Housing Regimes of the Transi-tion Countries - the Case of Hungary. In J. Doling, M. Elsinga (eds.). Home-Ownership: Getting In, Getting Out, Getting From. Amsterdam: IOS Press. 2006, 175-200.

26. Higgs, P., Gilleard, C. Generational Conflict, Consumption and the Ageing Welfare State in the United Kingdom. Ageing and Society, 2010, 30(8), 1439-1451.

27. Indriliūnaitè, R. „Tarpgeneracinè parama apsirūpinant būstu Lietuvoje“. Kultūra ir visuomene: socialiniu tyrimu žurnalas, 2019, 10(2), 109-127.

28. Indriliūnaitè, R. Socialinio būsto politikos samprata ir paramos būstui prieinamumo galimybès Lietuvoje. Kultūra ir visuomené: socialiniu tyrimu žurnalas. 2018, 9(2), 169-193.

29. Indriliūnaite, R., Žilys, A. Lietuvos būsto politikos keliami iššǔkiai jaunimui privačioje būsto valdoje, Viešoji politika ir administravimas, 2018, 17(3), 454-469. 
30. Ivanauskas, F., Eidukevičius, R., Marčinskas, A., Galinienè, B. Analysis of the Housing Market in Lithuania. International Journal of Strategic Property Management. 2008, 12 (4), 271-280.

31. Kemeny, J. From Public Housing to the Social Market: Rental Policy Strategies in Comparative Perspective. London: Routledge. 1995.

32. Kemeny, J. Housing and Social Theory. London: Routledge. 1992.

33. Lennartz, C. Power Structures and Privatization across Integrated Rental Markets: Exploring the Cleavage between Typologies of Welfare Regimes and Housing Systems. Housing, Theory and Society, 2011, 28 (4), 342-359.

34. Lennartz, C., Arundel, R., Ronald, R. Younger Adults and Homeownership in Europe through the Global Financial Crisis. Population, Space and Place, 2016, Vol. 22, No 8, 823-835.

35. Lennartz, C., Helbrecht, I. The Housing Careers of Younger Adults and Intergenerational Support in Germany's 'Society of Renters'. Housing Studies, 2018, 33(2), 317-336.

36. Lietuvos Respublikos Aukščiausioji Taryba-Atkuriamasis Seimas. Lietuvos Respublikos gyventojų apsirūpinimo gyvenamosiomis patalpomis įstatymas. 1992-04-07. I-2455. Valstybės žinios, 1992-05-20, Nr. 14-378.

37. Lietuvos Respublikos butų privatizavimo įstatymas. Valstybės žinios, 1991-06-20, Nr. 17449.

38. Lietuvos Respublikos Seimas. Lietuvos Respublikos finansinès paskatos pirmaji būstą ìsigyjančioms jaunoms šeimoms įstatymas. 2018 m. birželio $21 \mathrm{~d}$. Nr. XIII-1281. TAR, 201806-26, Nr. 10518.

39. Lietuvos Respublikos Seimas. Lietuvos Respublikos paramos būstui ịsigyti ir išsinuomoti istatymas. 2014. Nr. XII-1215. TAR, 2014-10-30. Nr. 15180.

40. Lietuvos Respublikos Seimas. Lietuvos Respublikos valstybès paramos būstui ịsigyti ar išsinuomoti ịstatymo ịgyvendinimo įstatymas. $2002 \mathrm{~m}$. lapkričio $12 \mathrm{~d}$. Nr. IX-1189. Valstybès žinios, 2002-12-06, Nr. 116-5189.

41. Lietuvos Respublikos Vyriausybès nutarimas. Dèl valstybès remiamos programos „Būstas“. 1992 m. liepos 17 d. Nr. 562. Valstybès žinios, 1992-09-30, Nr. 27-791.

42. Lietuvos Respublikos Vyriausybès nutarimas. Dèl Lietuvos būsto strategijos igyvendinimo 2004-2006 metų priemonių patvirtinimo. 2004 m. sausio 21 d. Nr. 60. Valstybės žinios, 200401-24, Nr. 13-387.

43. Lietuvos statistikos departamentas. 2003. Pranešimas spaudai. Nr. 5/144, rugsèjo $10 \mathrm{~d}$. https://osp.stat.gov.lt/documents/10180/212826/2003_09_10.pdf/282353ce-9aa9-45a9-a530d13a1839a386. [2019-11-05].

44. Mannheim, K. The Problem of Generations. In Essays on the Sociology of Knowledge, New York: Oxford University Press, 1952, 276-320.

45. McKee, K. Young Peope, Homeownership and Future Welfare. Housing Studies, 2012, Vol. 27, No 6, September, 853-862.

46. Mulder, C. H. The Family Context and Residential Choice: A Challenge for new Research. Population, Space and Place, 2007, 13(4), 265-278.

47. Mulder, C. H., Smits, A. Inter-Generational Ties, Financial Transfers and Home-Ownership Support. Journal of Housing and the Built Environment, 2013, 28(1), 95-112.

48. Ronald, R., Elsinga, M. Beyond Home Ownership: An overview. In R. Ronald, M. Elsinga (eds.). Beyond Home Ownership: Housing Welfare and Society. London. Routledge. 2012, 128.

49. Ruopilla, S. Housing Policy and Residential Differentiation in Post-Socialist Tallinn. European Journal of Housing Policy, 2005, 5 (3), 279-300.

50. Stone, J., Berrington, A., Falkingham, J. Gender, Turning Points, and Boomerangs: Returning Home in Young Adulthood in Great Britain. Demography, 2014, 51(1), 257-276. 
51. Teisès aktų, reglamentavusių teritorijų planavimo, statybos ir valstybinès statybos kontrolès tvarką Lietuvoje 1947-1992 metais, sąrašas. Valstybinè teritorijų planavimo ir statybos inspekcija prie aplinkos ministerijos. Vilnius. 2009.

52. Tosics, I., Hegedüs, J. Housing in South-Eastern Europe. In D. Clapham, J. Hegedüs, K. Kintrea, I. Tosics, H. Kay (ed). Housing Priva-tization in Eastern Europe. Westport, London: Greenwood Press. 1996, 169-189.

53. Tsenkova, S. Housing in Transition and the Transition in Housing: The Experience of Central and Eastern Europe. Sofia: Kapital Reklama. 2000.

54. Verslo žinios. Būstui šiuo metu dažniausiai skolinasi jauni specialistai. 2010-10-05. https://www.vz.lt/archive/straipsnis/2010/10/05/Bustui_siuo_metu_dazniausiai_skolinasi_ja uni_specialist [2020-03-05].

55. White, J. Thinking generations. The British Journal of Sociology, 2013, 64(2), 216-247.

56. Woodman, D., Wyn, J. Youth and Generation: Rethinking Change and Inequality in the Lives of Young People. London: Sage Publications Ltd. 2015.

57. Žilys, A. Būsto karjera ir jos trajektorijos demografinio gyvenimo ciklo pradžioje: Lietuvos jaunimo apsirūpinimo būstu situacija. Kultūra ir visuomenè: socialinių tyrimų žurnalas, 2018, 9(2), 193-227.

58. Žilys, A. Moderniosios Lietuvos urbanizacijos raida: būsto, teritorinio ir regioninio planavimo politika vėlyvojo sovietmečio ir ankstyvosios Lietuvos nepriklausomybės periodu (1987-1997 m.). Viešoji politika ir administravimas. 2019, T. 18, Nr. 3, 20-34.

Rasa Indriliūnaitè

\section{Possibilities of Self-Provision of Housing for the Middle Generation (born in 1970-1984) in Lithuania}

Abstract

The article analyzes possibilities of individual self-provision of housing in Lithuania which are defined by a dualistic housing policy model. The model emerged after independence was restored, and is mainly characterised by a limited degree of responsibility of the state for housing needs of residents and a private housing fund controlled by the market players. In recent decades, many modern housing policy systems are undergoing intense changes due to the effects of financial crises and the challenges posed by a shrinking welfare state. A growing private housing sector and decreasing state support for housing are evident in dualistic and unitary housing systems. Structural changes in the labour market and demographic changes in society complicate the issue of selfprovision of housing for representatives of younger generations. Researchers agree that older generations were more privileged in the housing sector and had better possibilities to self-provide housing. The article aims at disclosing the context of possibilities for private self-provision of housing for representatives of the middle generation (born in 1970-1984) in Lithuania. Since this generation, as a separate cohort, has not received sufficient attention yet, it is worth distinguishing it because this generation, in the active period of their marital life, has experienced a rapid change in the society and structural, economic and political changes, as well as changes in the housing policy. All these changes make this generation different from older generations that lived in the environment of the Soviet housing provision system and the youngest generations that were socialized under conditions of liberal economics and dominating private housing ownership. 
Rasa Indriliünaite - Doctor of Social Sciences, Researcher at the Social Resarch Center, Faculty of Social Sciences, Vytautas Magnus University.

E-mail: rasa.indriliunaite@vdu.lt

Rasa Indriliūnaitè - Vytauto Didžiojo universiteto Socialinių mokslų fakulteto Socialinių tyrimų centro mokslo darbuotoja, socialinių mokslų daktarè.

El. paštas: rasa.indriliunaite@vdu.lt 